\title{
Effect of Chocolate Soybean Drink on Nutritional Status, Gamma Interferon, Vitamin D, and Calcium in Newly Lung Tuberculosis Patients
}

\author{
Nurpudji Astuti Taslim ${ }^{1 *}$, Haerani Rasyid ${ }^{1}$, Mellyana Kusuma Atmanegara ${ }^{2}$, Sigit Angriavan ${ }^{3}$, Rezky Amelia $^{3}$ \\ ${ }^{1}$ Nutrition Department, School of Medicine, Hasanuddin University, Makassar, Indonesia; ${ }^{2}$ Graduate Student, Nutrition \\ Department, Div. Clinical Nutrition, Hasanuddin University, Makassar, Indonesia; ${ }^{3}$ Graduate Student, Nutrition Department, \\ Faculty of Public Health, Hasanuddin University, Makassar, Indonesia; ${ }^{4}$ Center for the Study of Food, Nutrition and Health, \\ Hasanuddin University, Makassar, Indonesia
}

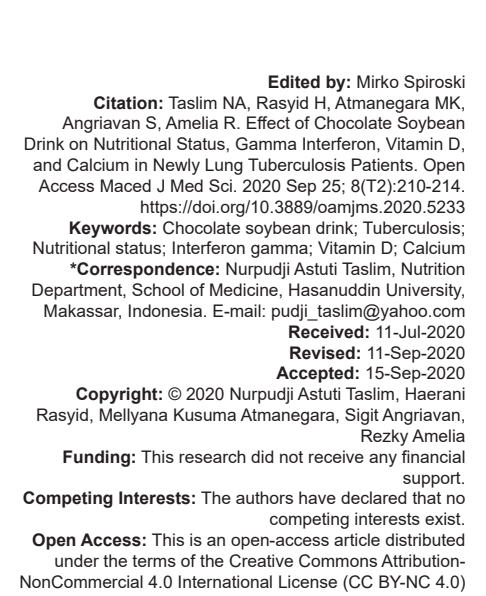

Introduction

It is estimated that 10 million people in the world were found to be infected by tuberculosis (TB). In 2017, TB infection was found in 5.6 million on men, 3.2 million on women, and 1 million children. Nine percent of TB patients were found to have HIV infection (in which $72 \%$ found in Africa) and $2 / 3$ of it was found in India (27\%), China (9\%), and Indonesia (8\%) [1]. The prevalence of TB in Indonesia (2014) was 297 over 100,000 population. In 2017, it was estimated 10 million of TB incident were found (133 cases over 100,000 population). The WHO Southeast Asia and Africa recorded for almost $70 \%$ of all TB cases in the world.

Data taken from Ditjen P2P, Ministry of Health - Republic of Indonesia in January 31, 2019, showed that Indonesia had 511,873 TB patients. The number of confirmed new cases of TB with positive bacteriology in 2018 was 203,348 patients. East Java had the highest number of TB patients. South Sulawesi had 23,427 patients.

One of the characteristics of facultative intracellular bacteria, Mycobacterium tuberculosis, is the ability of being survived and multiplying within phagocyte cells and being able to hide from host's circulating antibody. Hence, eliminating this kind of bacteria requires effective cell-mediated immunity [2].

Inhaling a TB pathogen can stimulate a cellmediated immune response that initiates an inflammation process. The increase of pro-inflammatory cytokines such as IL-6, TNF $\alpha$, IL-1 $\beta$, and IFN- $\gamma$ can make a metabolic change in TB patients. This process is called an anabolic block, where there is inhibition of protein formation and fat synthesis and an increase of proteolysis and lipolysis to produce free fatty acids (FFA) as an energy source for bacteria and increase virulence. Eventually, malnutrition is a common finding in TB patients [3].

IFN- $\gamma$ increases phagocytosis function of a M. tuberculosis infected macrophage by stimulating 
phagolysosome formation. IFN- $\gamma$ stimulates the formation of free radical to destruct DNA and cell wall of $M$. tuberculosis. IFN- $\gamma$ in TB patients is found to be significantly lower than the healthy population [4]. Nutritional intervention that can increase IFN- $\gamma$ as one of body's defense against lung TB infection is an important action. A quasi-experiment controlled design study conducted by Nurpudji [5] on TB patient in BBKPM Makassar, found that nutritional education and a high protein as a supplementary feeding (soy protein) could improve the nutritional status of TB patients.

Isoflavone genistein is an active substance that plays an important role in this case. Isoflavone in soybean significantly suppressing expression of a mature dendritic cell within the immune system in Type I MHC but not Type II MHC in in vitro study. Isoflavone inhibits lipopolysaccharide in dendritic cells to induce IFN-y in CD4+ T cell. Degranulation of a natural killer cell (NK cell) and apoptosis of dendritic cells is found to be significantly higher in isoflavone administration in dendritic and NK cells study [4].

In an in vivo study, as well as soybean, cocoa has a high protein and fat content. Cocoa bean or chocolate can increase serotonin neurotransmitter release, hence, will increase appetite. It also contains a high flavonoid, an antioxidant that can increase the function of immune system [6]. Administration of both soybean and cocoa can increase calorie and protein intake in lung TB patients. Type of protein given is a protein that can increase immune system function and appetite, hence, can increase their nutritional status.

The importance of this study is considering a fulfillment of calorie, protein composition, and flavonoid, along with an increase of appetite and antioxidant administration from chocolate soybean drink (CSD). This study aimed to assess the effect of chocolate soybean milk to nutritional status, interferon-gamma level, Vitamin $\mathrm{D}$ level, and sputum conversion in lung TB patients.

\section{Materials and Methods}

This study uses a quasi-experimental study design using pre- and post-test in two groups. Purposive sampling, a non-probability sampling method, was used. The population in this study is lung TB patients in the lung medical center in Makassar (BBKPM) and Wahidin Sudirohusodo Hospital, Makassar. Diagnosis of TB was done by acid-fast bacilli (AFB) sputum examination, erythrocyte sedimentation rate, and thorax photo. Sample in this study is a newly diagnosed lung TB patient with positive AFB sputum, normal urinalysis and had no history of antituberculosis treatment.

Data collection was done in 2 phases. Phase 1, we performed a screening to determine sample followed by assessing samples that fulfilling our criteria. After samples had been decided, we divided samples into two groups: Intervention group and control group. In phase, we collected data from all variables in this study. In intervention groups, we gave 100 grams of CSD and nutritional education, whereas in the control group, we only gave nutritional education. Before intervention, we did a pre-test assessment for nutritional status, food intake measurement, interferon-gamma, Vitamin $D$ and calcium examination, and AFB sputum examination. After 4 weeks of observation, we did a post-test assessment for nutritional status food intake measurement, interferongamma, Vitamin D and calcium examination, and AFB sputum examination.

Statistical analysis was done using SPSS after underwent a normality test. An independent t-test was used to compare anthropometric, food intake, and laboratory data form both groups. For abnormal distribution, we used the Mann-Whitney test. $p<0.05$ used to determine significance. Ethical clearance was given by the ethical committee of Universitas Hasanuddin for Biomedical Research in human.

\section{Results}

Table 1 showed that most of the samples were male in both groups $(47 \%$ in the intervention group and $94.1 \%$ in the control group) and below 50 years old $(94.1 \%$ in the intervention group and $82.3 \%$ in the control group). In ethic group classification, Makassar was dominating in both groups (67.4\%). In occupation classification, unemployed group was dominating $(64.6 \%$ in the intervention group and $52.8 \%$ in the

Table 1: Distribution of the socio-demographic characteristics of the two groups of research subjects (intervention and control group)

\begin{tabular}{|c|c|c|c|c|c|c|}
\hline Variable & $\begin{array}{l}\text { Intervention } \\
\mathrm{n}=17\end{array}$ & $\%$ & $\begin{array}{l}\text { Control } \\
n=17\end{array}$ & $\%$ & $\begin{array}{l}\text { Total } \\
n=34\end{array}$ & $\%$ \\
\hline \multicolumn{7}{|l|}{ Gender } \\
\hline Male & 8 & 47.0 & 16 & 94.1 & 24 & 70.6 \\
\hline Female & 9 & 53.0 & 1 & 5.9 & 10 & 29.4 \\
\hline \multicolumn{7}{|l|}{ Age } \\
\hline$\leq 50$ year old & 16 & 94.1 & 14 & 82.3 & 30 & 88.2 \\
\hline$>50$ year old & 1 & 5.9 & 3 & 17.7 & 4 & 11.8 \\
\hline \multicolumn{7}{|l|}{ Ethnic Group } \\
\hline Makassar & 13 & 76.4 & 10 & 58.8 & 23 & 67.4 \\
\hline Bugis & 2 & 11.8 & 5 & 29.4 & 7 & 20.6 \\
\hline Toraja & 2 & 11.8 & - & 0.0 & 2 & 5.9 \\
\hline Flores & - & 0.0 & 1 & 5.9 & 1 & 3.05 \\
\hline Manado & - & 0.0 & 1 & 5.9 & 1 & 3.05 \\
\hline \multicolumn{7}{|l|}{ Occupation } \\
\hline Civil Servant & 1 & 5.9 & 1 & 5.9 & 2 & 5.8 \\
\hline Retired & - & 0.0 & 1 & 5.9 & 1 & 3.05 \\
\hline Entrepreneur & 4 & 23.5 & 3 & 17.6 & 7 & 20.5 \\
\hline Private Employee & 1 & 5.9 & - & 0.0 & 1 & 3.05 \\
\hline Laborer/unemployed & - & 64.6 & 10 & 58.8 & 21 & 61.7 \\
\hline Housewife & 2 & 11.8 & - & 0.0 & 2 & 5.8 \\
\hline Fisherman & - & 0.0 & 1 & 5.9 & 1 & 3.05 \\
\hline \multicolumn{7}{|l|}{ Education } \\
\hline No education Elementary & - & 0.0 & 1 & 5.9 & 1 & 3.05 \\
\hline School & 3 & 17.7 & 3 & 17.7 & 6 & 17.6 \\
\hline Middle School & 8 & 47.0 & 3 & 17.7 & 11 & 32.3 \\
\hline High School & 5 & 29.4 & 7 & 41.0 & 12 & 35.2 \\
\hline University & 1 & 5.9 & 3 & 17.7 & 4 & 11.8 \\
\hline
\end{tabular}


control group). According to the educational level, high school graduated group was the highest $(35.2 \%)$ followed by junior high school graduated (32.3\%).

Table 2 showed results of statistical analysis for mean distribution of age, anthropometry study (body height, body weight, body mass index, and mid-arm circumference), and laboratory results including IFN-y, white blood cell count, lymphocyte count, lymphocyte percentage, granulocyte count, granulocyte percentage, and hemoglobin $(\mathrm{Hb})$. These data showed no statistical difference between groups ( $p>0.05)$.

Table 2: Comparative analysis of anthropometric measurements by group before and after intervention

\begin{tabular}{llllll}
\hline Variable & Pre-test & Post-test & p value & A & p value \\
\hline Body Weight $(\mathrm{kg})$ & & & & & \\
$\quad$ Intervention & $44.11 \pm 4.88$ & $45.50 \pm 4.77$ & $0.000 \#$ & $11.38 \pm 0.51$ & $0.000^{*}$ \\
$\quad$ Control & $44.98 \pm 4.48$ & $45.48 \pm 4.34$ & $0.000 \#$ & $0.49 \pm 0.45$ & \\
$\begin{array}{l}\text { Mid Upper Arm Circumference }(\mathrm{cm}) \\
\quad \text { Intervention }\end{array}$ & $22.17 \pm 2.68$ & $22.63 \pm 2.73$ & $0.000 \#$ & $0.46 \pm 0.18$ & $0.716^{*}$ \\
$\quad$ Control & $22.06 \pm 1.54$ & $22.64 \pm 2.03$ & $0.085 \#$ & $0.58 \pm 1.30$ & \\
Body Mass Index & & & & & \\
$\quad$ Intervention & $17.24 \pm 0.91$ & $17.79 \pm 0.87$ & $0.000 \#$ & $0.54 \pm 0.22$ & $0.000^{*}$ \\
$\quad$ Control & $17.64 \pm 1.20$ & $17.84 \pm 1.21$ & $0.001 \#$ & $0.20 \pm 0.20$ & \\
\hline
\end{tabular}

Table 3 showed mean energy intake before intervention, which was $1308 \mathrm{kcal}$ in the intervention group and $1238 \mathrm{kcal}$ in the control group. Protein intake was $42.72 \mathrm{~g}$ in the intervention group and $42.7 \mathrm{~g}$ in the control group. Statistical analysis showed equality in energy, carbohydrate, protein, and fat intake before intervention in both groups.

Table 3: Comparative analysis of average intake of energy, macro-nutrients, calcium and Vitamin $D$ in the two research subject groups (intervention group and control group) before and after intervention

\begin{tabular}{|c|c|c|c|c|c|}
\hline Variable & Pre-test & Post-test & p value ${ }^{*}$ & $\Delta$ & $p$ value ${ }^{* *}$ \\
\hline \multicolumn{6}{|l|}{ Energy (kcal) } \\
\hline Intervention & 1.308 .0 & 2.119 .50 & 0.000 & $\uparrow 811.34 \pm 175.33$ & \multirow[t]{2}{*}{0.538} \\
\hline Control & 1.238 .0 & 2.014 .62 & 0.000 & $\uparrow 776.86 \pm 146.04$ & \\
\hline \multicolumn{6}{|l|}{ Protein (gram) } \\
\hline Intervention & 42.72 & 97.20 & 0.000 & $\uparrow 54.55 \pm 12.41$ & \multirow[t]{2}{*}{0.000} \\
\hline Control & 42.70 & 68.72 & 0.000 & $\uparrow 25.93 \pm 15.02$ & \\
\hline \multicolumn{6}{|l|}{ Fat (gram) } \\
\hline Control & 24.0 & 56.20 & 0.000 & $\uparrow 31.96 \pm 16.61$ & \multirow[t]{2}{*}{0.126} \\
\hline Intervention & 20.80 & 45.37 & 0.000 & $\uparrow 24.56 \pm 10.01$ & \\
\hline \multicolumn{6}{|c|}{ Carbohydrate (gram) } \\
\hline Intervention & 224.02 & 280.20 & 0.000 & $\uparrow 56.26 \pm 49.13$ & \multirow[t]{2}{*}{0.001} \\
\hline Control & 216.60 & 328.50 & 0.000 & $\uparrow 111.83 \pm 33.26$ & \\
\hline \multicolumn{6}{|l|}{ Calcium (mg) } \\
\hline Intervention & 239.5 & 696.16 & 0.000 & $\uparrow 456.61 \pm 208.33$ & \multirow[t]{2}{*}{0.000} \\
\hline Control & 137.5 & 288.85 & 0.000 & $\uparrow 151.29 \pm 69.13$ & \\
\hline \multicolumn{6}{|c|}{ Vitamin D (ngml) } \\
\hline Intervention & 7.46 & 9.85 & 0.236 & $\uparrow 2.39 \pm 4.01$ & \multirow[t]{2}{*}{0.247} \\
\hline Control & 6.50 & 8.77 & 0.197 & $\uparrow 2.27 \pm 8.49$ & \\
\hline
\end{tabular}

Table 4 showed an increase in body weight, mid-upper arm circumference, and body mass index after intervention. Comparative analysis before and after intervention was done in both groups. Statistical test showed a significant difference in body weight

Table 4: Analysis of laboratory test results for calcium, Vitamin D, IFN $\gamma$ by group before and after intervention

\begin{tabular}{llllll}
\hline Variable & Pre-test & Post-test & $p$ value & $\Delta$ & p value \\
\hline Calcium $(\mathrm{mg})$ & & & & & \\
$\quad$ Intervention & $9.41 \pm 0.45$ & $9.43 \pm 0.94$ & 0.210 & $\uparrow 0.02 \pm 1.16$ & 0.169 \\
$\quad$ Control & $9.24 \pm 0.52$ & $8.92 \pm 1.67$ & 0.571 & $\downarrow 0.24 \pm 3.21$ & \\
$\begin{array}{l}25(\mathrm{OH}) \mathrm{D} 3(\mathrm{ng} / \mathrm{mL}) \\
\quad\end{array}$ & & & & & \\
$\quad$ Intervention & $21.176 \pm 8.28$ & $21.35 \pm 6.15$ & 0.666 & $\uparrow 0.17 \pm 9.7$ & 0.133 \\
$\quad$ Control & $24.882 \pm 11.36$ & $22.841 \pm 9.70$ & 0.652 & $\downarrow-2.05 \pm 4.82$ & \\
$\begin{array}{l}\text { IFN- } \gamma(\mathrm{pg} / \mathrm{ml}) \\
\quad \text { Intervention }\end{array}$ & $16.34 \pm 10.29$ & $44.61 \pm 25.56$ & 0.000 & $28.27 \pm 1.79$ & $0.001^{\text {** }}$ \\
$\quad$ Control & $12.28 \pm 5.01$ & $21.62 \pm 8.83$ & & & \\
\hline
\end{tabular}

$(p=0.000)$ and body mass index $(p=0.000)$ but not significant in mid-upper arm circumference $(p=0.716)$.

Table 5 showed a comparative analysis between changes on IFN-y, WBC, lymphocyte count, lymphocyte percentage, granulocyte count, granulocyte percentage, and $\mathrm{Hb}$ level. Changes on IFN-y and $\mathrm{Hb}$ level were found to be significant $(p=0.001$ and 0.036 , respectively)

Table 5: The results of sputum AFB before and after the intervention

\begin{tabular}{|c|c|c|c|c|c|c|c|c|}
\hline \multirow[t]{3}{*}{ AFB Sputum } & \multicolumn{4}{|c|}{ Intervention Group $(\mathrm{n}=17)$} & \multicolumn{4}{|c|}{ Control Group $(n=17)$} \\
\hline & \multicolumn{2}{|c|}{ Pre-test } & \multicolumn{2}{|c|}{ Post-test } & \multicolumn{2}{|c|}{ Pre-test } & \multicolumn{2}{|c|}{ Post-test } \\
\hline & $\mathrm{n}$ & $\%$ & $\mathrm{n}$ & $\%$ & $\mathrm{n}$ & $\%$ & $\mathrm{n}$ & $\%$ \\
\hline Positive (+) & 17 & 100 & 9 & 52.9 & 17 & 100 & 14 & $\overline{82.4}$ \\
\hline Negative (-) & 0 & 0 & 8 & 47.1 & 0 & 0 & 3 & 17.6 \\
\hline Total & 17 & 100 & 17 & 100 & 17 & 100 & 17 & 100 \\
\hline
\end{tabular}

\section{Discussion}

This study showed the effect of CSD to nutritional status and IFN-y level in two groups (intervention group and control group). We performed a non-randomized controlled clinical trial comparing intervention group (100 g/day of CSD along with nutritional education) to the control group (only nutritional education) in lung TB patients.

Nutritional intake assessed using $24 \mathrm{~h}$ food record during intervention in food history form. However, this method required commitment from subjects to take a note for every food they ate, both its type and amount. This strategy was aimed to decrease the tendency of subjects who were possible to forget what they ate. Hence, this type of bias could possibly be decreased. Moreover, ensuring the homogeneity perceptions in food intake using food models and analyzed using Nutrisurvey Indonesia.

Administration of fusion between soybean and cocoa in the form of a daily 100-g liquid had high energy (523 kcal) and protein $(40.71 \mathrm{~g})$. This soybean chocolate drink was given in 30 days showed a positive effect in increasing calorie and protein intake in lung TB patient. The type of protein given was a protein that can increase the immune system and appetite; hence, it can increase their nutritional status.

Our study showed a fulfillment of calorie, protein composition, and flavonoid intake in the intervention group. Moreover, we also found an increase of appetite and fulfillment of antioxidant in the soybean chocolate drink administration. Therefore, a significant improvement on body mass index (BMI) and increased IFN-y in the intervention group compared to the control group. The increase of BMl indicates an increase in body weight.

The increase of energy and protein intake was higher in the intervention group. This might be 
due to a high protein supplementary food given in the intervention group. This supplementary feeding increased energy and protein intake in which was necessary in malnutrition patient. We also found a similar increase in the control group that was due to increased appetite after treatment and changes in food intake (amount and type) after nutritional education. Information about recommended for lung TB was given during nutritional education; thus, participants changed their food (type and amount) accordingly. The quality and quantity of protein recommended were given, for example, fresh fish, egg, milk, green beans, tofu, soybean cake, chicken, and beef.

Our study showed a higher increase in body weight in the intervention group $(1.38 \mathrm{~kg})$ compared to the control group $(0.49 \mathrm{~kg})$. Karyadi [7] found a higher increase in body weight in their intervention group compared to their control group. This increase within 2 months in the interventional and control group were $2.20 \pm 0.35 \mathrm{~kg}$ and $2.19 \pm 0.35 \mathrm{~kg}$, respectively. Within 6 months, body weight increase in the intervention group and the control group were $4.74 \pm 0.42 \mathrm{~kg}$ and $4.96 \pm 0.48 \mathrm{~kg}$, respectively. Body weight increase was associated with an increase of energy intake and physiological need fulfillment. In the first phase, energy and protein intake are used for physiologic needs followed by consumption for physical activities and fulfillment of macronutrient reservoir (carbohydrate, protein, and fat). This reservoir fulfillment can be seen in body weight increase and other anthropometric measurements.

Analysis on mid-upper arm circumference (MUAC) measurement showed an insignificant increase in both groups. Moreover, both data had not reached normal MUAC value (> $23.5 \mathrm{~cm})$. MUAC increase in the intervention group was found to be higher $(22.17 \pm 2.68 \mathrm{~cm}$ before intervention to $22.63 \pm 2.73 \mathrm{~cm}$ after intervention) than control group $(22.06 \pm 1.54 \mathrm{~cm}$ before intervention to be $22.64 \pm 2.03 \mathrm{~cm}$ after intervention). MUAC is an indicator for assessing protein reservoir in muscle in which is usually low in malnourished people. Despite a statistically insignificant difference, the increase of MUAC indicates an increase of endogenous protein storage in which is associated with protein intake. Compared to study by Karyadi [7] in the second month, MUAC in the intervention group was $22.8 \pm 0.3 \mathrm{~cm}$ before intervention and $23.4 \pm 0.4 \mathrm{~cm}$ after intervention, where they found $21.8 \pm 0.6 \mathrm{~cm}$ before intervention and $22.8 \pm 0.6 \mathrm{~cm}$ after intervention in the control group.

Body mass index in this study was increased in both groups, although still below the normal range (> 18.5-23). This might be due to limitations in the duration of the study which was only 1 month. We predict had the study been done for 6 months, it would have been possible to reach a normal range of BMI. This finding was similar to the study by Karyadi [7] in which BMI reached normal value after 6 months. The increase of BMI in adult is due to an increase of body weight. In an interventional study, BMI increase was higher than the control study.

Malnutrition is associated with a decrease of immune system. According to Chandra [8], nutritional status is associated with susceptibility to infectious diseases such as TB. Nutritional deficiency makes decrease and dysfunction of immune response, phagocyte function, cytokine production, and complement system. Increase of IFN-y was found in both groups $(p=0.001)$ which were higher in the intervention group. Chandra [8] also found that adequate nutritional intake, especially protein, could activate the cellular immune system, whereas IFN-y was the part of it. IFN-y is an important immunoregulator that has multiple effects in maturation and function of immune system to fight against TB [9]

According to Kaur [10] oxidative stress and reduced antioxidant were found in lung TB patients. Appropriate antioxidant supplement is needed for lung TB patients for protection against free radical [11]. Twenty-two milligram of flavonoid contained within a $100 \mathrm{~g}$ of CSD. In most Asian countries, isoflavone (flavonoid) consumption assumed to be 25-45 mg/day. Antioxidant feature in isoflavone makes an improvement in the immune system [12].

The availability of nutrients derived from food is associated with body defense against free radicals. Isoflavone contained in soybean is one of the natural antioxidant (Retno et al., 2012). Many studies showed that isoflavone as a phenol derived antioxidant can be found in soybean and other legumes. It has a positive effect on inflammation and improves immune function both in vitro and in vivo [13]. Our study showed that the administration of a 100-g CSD contained $440 \mathrm{mg}$ calcium. Consumption for 30 days had a benefit to increase calcium intake in lung TB patients.

Calcium intake was found to be higher in the intervention group. CSD consumption could increase calcium intake in lung TB patients in which often had low intake in calcium. The increase of calcium intake was also found in the control group due to appetite improvement after consuming antituberculosis treatment and food amount and variation after nutritional education. Food recommendation was informed in our nutritional education in both groups, including the food amount and variations.

According to Baig [14], calcium and Vitamin D had an antimicrobial feature against TB by enhancing macrophage and monocyte function by increasing nitric oxide (NO) production. Intake of Vitamin D in both groups increased insignificantly. The highest increase occurred in the intervention group. Analysis of the differences between the two groups also showed insignificant values. If these results are compared with the 2013 recommended daily allowance (Angka Kecukupan Gizi or $A K G)$, vitamin $D$ intake at the age of 3-64 years is 
15 mcg. Acid-fast bacilli (AFB) sputum conversion from positive to negative was higher in the intervention group (47.1\%) compared to the control group (17.6\%). Thus, a daily CSD for 4 weeks can accelerate the conversion of sputum in the intervention group.

\section{Recommendation}

We suggest that further research is needed for evaluating the effect of CSDs with a longer intervention time to evaluate a better nutritional status in lung TB patients. Moreover, further research is needed to measure the levels of serum antioxidants in both groups.

\section{References}

1. World Health Organization. Global Tuberculosis Report. Geneva: World Health Organization; 2019.

2. Cavalcanti YV, Brelaz MC, Neves JK, Ferraz JC, Pereira VR. Role of TNF-alpha, IFN-gamma, and IL-10 in the development of pulmonary tuberculosis. Pulm Med. 2012;2012:745483. https://doi.org/10.1155/2012/745483

PMid:23251798

3. Taslim NA, Virani D, Sumartini NK, Rasyid H, Bukhari A, Satriono $\mathrm{R}$, et al. Energy regulation in newly diagnosed TB with chronic energy deficiency: Free fatty acids and RBP4. Asia Pac J Clin Nutr. 2017;26(Suppl 1):S73-8. PMid:28625041

4. Teguh W, Diana KJ, Rina LR. Analisis Kadar Interferon Gamma Pada Penderita Tuberkulosis Paru dan Orang Sehat. Jakarta:
Bagian Pulmonologi Fakultas Kedokteran Universitas Kristen Maranatha; 2010.

5. Nurpudji AT. Penyuluhan gizi, pemberian soy protein dan perbaikan status gizi penderita tuberculosis di Makassar. J Med Nus. 2004;25:59-64.

6. Erniati Z, Dan Priosoeryanto FR. Efek konsumsi minuman bubuk kakao (Theobroma cacao L.) bebas lemak terhadap sifat antioksidatif limfosit subyek perempuan. J Teknol Ind Pangan. 2012;23(1):81-5

7. KaryadiE.Tuberculosisin Indonesia:Nutrition, Immune Response andSocialAspects;2001.Availablefrom:http://www.researchgate .net/publication/40191443 TuberculosisinIndonesianutritionim muneresponseandsocialaspects. [Last accessed on 2020 Feb 14].

8. Chandra RK. Nutrition, immunity and infection: From basic knowledge of dietary manipulation of immune responses to practical application of ameliorating suffering and improving survival. Proc Natl Acad Sci U S A. 1996;93(25):14304-7. https://doi.org/10.1073/pnas.93.25.14304 PMid:8962043

9. Subagyo A, Aditama TY, Sutoyo DK. Pemeriksaan interferon gamma dalam darah untuk deteksi infeksi tuberkulosis. J Tuberk Indones. 2006;3(2):6-19.

10. Kaur K, Kishan J, Bedi GK, Ahi RS. Oxidants stress and antioxidants in pulmonary tuberculosis. Chest. 2005;128(4):397. https://doi.org/10.1378/chest.128.4_meetingabstracts.397s-b

11. Mohod K, Archana D, Satish K. Status of oxidants and antioxidants in pulmonary tuberculosis with varying bacillary load. J Exp Sci. 2011;2(6):35-7.

12. Imanullah A. Manfaat Isoflavon Dalam Kedelai; 2009. Available from: http://www.ayubimanu.com/2009/01/manfaat-isoflavondalam-kedelai.html. [Last accessed on 2020 Feb 14].

13. Ryan-Borchers TA. Soy isoflavones modulate immune function in healthy postmenopausal women. Am J Clin Nutr. 2006;83(2):1118-25. PMid: 16685055

14. Baig A. Low Serum Calcium Associated with Tuberculosis. Karachi, Pakistan: Dow University of Health Science; 2006. 